International Business Management 13 (9): 397-404, 2019

ISSN: $1993-5250$

(C) Medwell Journals, 2019

\title{
Empirical Study of Bank Efficiency in Indonesia
}

\author{
${ }^{1}$ Ferry Ardiansyah, ${ }^{1}$ Hermanto Siregar, ${ }^{2}$ Dedi Budiman Hakim and ${ }^{1}$ Mulya E. Siregar \\ ${ }^{1}$ Business School at Bogor Agricultural University, Bogor, Indonesia \\ ${ }^{2}$ Departement of Economics, Bogor Agricultural University, Bogor, Indonesia
}

\begin{abstract}
To be able to achieve the best level of efficiency, the bank must be able to manage the inputs owned and the outputs produced in between. In addition, banks must also be able to manage operational costs and operating income. In this analysis of efficiency is calculation of the ratio between input and output variables. This research is using non-parametric Data Envelopment Analysis (DEA) for bank in Indonesia in group level two (BUKU II) banks which registered at IDX with period of analysis in 2014-2018. To analyze its efficiency by using intermediary and production approach. The sample analysis are taken from all population banks in BUKU II that already go public which consist of two sharia banks and sixteen conventional banks (four Foreign banks, one state-owned bank and eleven national private banks). The results of the study indicate that there are several banks that are able to achieve a level of efficiency both using the intermediation approach and also the production approach. In 2014, there were two Foreign banks that were able to achieve efficiency levels. In 2015, only one Foreign bank was able to achieve efficiency levels. However, in 2016 and 2017 none of the banks was able to reach the level of efficiency. In 2018 there were three banks that were able to achieve a level of efficiency using the intemediation and production approach, namely one sharia bank and two Foreign banks. The results of this study are expected to be useful for evaluating the level of efficiency that occurs in banks in Indonesia
\end{abstract}

Key words: Data envelopment analysis, banking efficiency, go public, intermediary approach, production approach

\section{INTRODUCTION}

Background: The development of regional and global dynamics and to support Indonesia's economic growth in an optimal and sustainable manner, it is necessary to increase the resilience, competitiveness and efficiency of the national banking industry. In order to increase the resilience, competitiveness and efficiency of national banks, it is necessary to arrange the scope of business activities and open office networks that are adjusted to the bank's capital capacity. This condition is considered by bank Indonesia by issuing Bank Indonesia Regulation No. 14/26/PBI/2012 concerning business activities and office networks based on Bank Core Capital. Article 1 paragraph 4 states that commercial banks are based on business activities, here in after referred to as BOOKS, are groups of banks based on business activities that are adjusted to their core capital.

Until June, 2019, of the fifty-nine BUKU 2 banks, there are eighteen BUKU 2 banks that have gone public or listed their shares on the Indonesia stock exchange. Trend performance of Bank BUKU II go public can be seen in Fig. 1.

Assets at the BUKU II banks go public during 2015-2018 continued to show positive growth. In 2016, the assets of BUKU II banks going public grew by $11.67 \%$ in 2017 and 2018 each grew by 9.35 and $6.62 \%$.

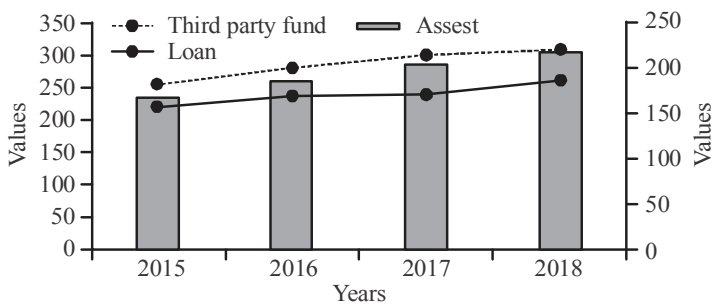

Fig. 1: Performance bank BUKU UU go public (Indonesian Banking Statistics-Financial Services Authority)

As for lending provided by BUKU II banks going public during 2015-2018 showed positive growth. In 2016 the credit provided by BUKU II banks go public was able to grow by $8.13 \%$ and in 2017 it experienced a decline with loans that were able to grow only $1.09 \%$. In 2018 , BUKU II banks go public to be able to increase the growth of lending to $8.81 \%$. Positive growth also occurred in the collection of third party funds made by BUKU II banks going public during the period 2015-2018. In 2016 third party fund raising grew by $9.60 \%$, then in 2017 the growth of third party funds fell to $7,20 \%$. In 2018 the growth of third party funds will decrease to $2.64 \%$.

Furthermore, for the development of assets, loans and third party funds that occurred at the BUKU II bank going 
Int. Business Manage., 13 (9): 397-404, 2019

Table 1: Income dan expenses bank BUKU II go public (in Rp Billion)

\begin{tabular}{lrrrr}
\hline Information & \multicolumn{1}{c}{2015} & \multicolumn{1}{c}{2016} & 2017 & 2018 \\
\hline Interest income & 23.593 & 26.302 & 25.815 & 26.961 \\
Interest expense & 13.781 & 14.609 & 12.713 & 12.298 \\
Net interest income & 9.811 & 11.594 & 13.101 & 14.663 \\
Non interest income & 2.401 & 2.925 & 3.229 & 5.612 \\
Non interest expense & 10.769 & 13.609 & 14.855 & 17.078 \\
Operational income & 25.993 & 29.129 & 29.044 & 32.573 \\
Interest expense & 24.550 & 28.218 & 27.568 & 29.376 \\
Interest profit & 1.443 & 911 & 1.476 & 3.197 \\
\hline (Indonesian Banking Statistics-Financial Services Authority)
\end{tabular}

public, operating income and operating expenses at the BUKU II bank going public had growth that was not in line with the development of loans and third party funds over a certain period of time (Fig. 1). In 2017, BUKU II bank went public, third party fund raising was able to grow by $7.20 \%$ but the operating expenses incurred in 2017 showed a decrease of $-2.30 \%$. Likewise, lending in 2017 was still able to grow by $1.09 \%$ but operating income decreased by $-0.29 \%$. In 2018 there was also a condition where the collection of third party funds grew by only $2.64 \%$ but the operational burden on BUKU II banks grew by $6.56 \%$.

The developments that shown in Table 1, BUKU II bank go public require a more in-depth analysis of how operational management affected the revenues and operational costs of the positions in 2014-2018 from each of the banks in the BUKU II bank group. The diversity of performance results occurring at banks in the BUKU II group cannot be separated from the results of business and operational processes carried out by each bank. In running a business and its operations, banks are required to be able to run it efficiently. To be able to achieve the best level of efficiency, banks must be able to manage their inputs including third-party funds that have been successfully collected and the resulting output including loans. In addition, banks must also be able to manage operational costs and operating income. This certainly becomes its own challenge how efficient the efforts made both by banks in the BUKU II group, especially, those who go public to be able to manage their operations in order to be able to do efficiency.

Problem formulation: The developments that took place at the BUKU II bank go public as stated, demanding that banks in general and especially, banks at BUKU II are required to be able to manage existing inputs to produce maximum output and optimize existing inputs for the output produced. This then raises questions related to how to manage efficiency, namely how the level of efficiency in banks in the BUKU II group goes public based on the intermediation and production approach?

Research objectives: The research objective is to measure and analyze the level of efficiency of banks in the BUKU II go public based on the intermediation and production approaches.
Literature review: According to Farrell (1957) the efficiency of a company consists of two components, namely technical efficiency and allocative efficiency. Technical efficiency reflects the ability of the company to produce output with a number of available inputs. Whereas allocative efficiency reflects the company's ability to optimize the use of its inputs with its price structure and production technology. These two measures are then combined into economic efficiency. A company can be said to be economically efficient if the company can minimize production costs to produce certain outputs with a level of technology that is generally, used and prevailing market prices.

The parametric approach makes measurements using stochastic econometrics and seeks to eliminate interference from the effects of inefficiency. There are three econometric parametric approaches, namely: Stochastic Frontier Approach (SFA); Thick Frontier Approach (TFA) and Distribution-Free Approach (DFA). Meanwhile, the nonparametric approach with a linear program (Nonparametric Linear Programming Approach) performs nonparametric measurements using an approach that is not stochastic and tends to "combine" disturbances and inefficiencies. It builds on the findings and observations of the population and evaluates the relative efficiency of the units being observed. This approach is known as Data Envelopment Analysis (DEA). DEA is a mathematical programming technique that measures the level of efficiency of a Decision-Making Unit (UPK) or decision-making unit relative to a similar UPK when all of these units are on or below the frontier's efficient "curve".

This approach was first introduced by Charnes, Cooper and Rhodes in 1978. Since, then the application of this approach has increasingly developed (Denizer et al., 2000). Linear programming is very dependent on the population sampled, so, it tends to be far from specification errors (Kumbhaker and Lovell, 2000). Furthermore, the performance of one UPK is very relative to other UPKs, especially, those that cause inefficiency. This approach can also see how a UPK can improve its own financial performance, so that, it becomes efficient. The advantage of using DEA is that this approach does not require explicit specifications of the shape of the function and only requires a little structure to form its efficiency frontier. Weaknesses that may arise are "self identifier" and "near self identifier".

Efficiency measurements using the frontier approach have been used for over 40 years (Coelli et al., 1996). The main methods that use linear programming and econometrics methods are: data envelopment analysis and stokastic frontier. This measurement of modern efficiency was first pioneered by Farrell (1957) in collaboration with Debreu and Koopmans by defining a simple measure to measure the efficiency of a company 
that could account for large inputs. The efficiency intended by Farrell consists of technical efficiency (technical efficiency) which reflects the ability of a company to maximize output with certain inputs and allocative efficiency which reflects the ability of a company that utilizes inputs optimally with a predetermined price level. These two efficiency measures are then combined to produce economic (total) efficiency.

\section{MATERIALS AND METHODS}

Analysis method: The research design was carried out using Data Envelopment Analysis (DEA) to determine the efficiency values of the eighteen banks. In determining the efficiency value, two approaches are used, namely the intermediation approach and the production approach. The input and output variables for the two approaches are.

\section{Input variables-intermediation decisions:}

- Labor costs

- Third party funds

- $\quad$ Fixed assets

\section{Output variables-intermediation decisions:}

- Financing provided

- Operating income

- Current assets

\section{Input variables-production approval:}

- Operating costs

- Labor costs

- Other operating costs

\section{Output variables-production approval:}

- Operating income

- Other operating income

This research was conducted in June, 2019 until December, 2019 at commercial banks which are included in the BUKU II go public bank group in Indonesia. The study was conducted in Jakarta using secondary data with a span of January, 2014, to December, 2018. Secondary data is data from the publication of financial statements of each bank in the BUKU II bank group going public and other information. This report will be used for efficiency analysis with intermediaries and production. Secondary data is obtained through data access to the internal website of each bank that is the object of research as well as data sourced from external parties or third parties such as the Financial Services Authority (FSA) and or Bank Indonesia (BI) and the Indonesia stock exchange or other sources.
Efficiency analysis using data envelopment analysis techniques. Data Envelopment Analysis (DEA) is a method of optimizing a mathematical program that measures the efficiency of a Decision-Making Unit (DMU) and compares it relative to other DMUs. DEA analysis techniques are specifically, designed to measure the relative efficiency of a DMU under conditions of many inputs and outputs. The relative efficiency of a DMU is the efficiency of a DMU compared to other DMUs in a sample that uses the same type of input and output. DEA formulates DMU as a fractional linear program to find solutions, defining this model to be transformed into a linear program with the weighting values of inputs and outputs.

DEA assumes that each DMU will have a weight that maximizes its efficiency ratio (maximizing total weighted output/total weighted input). This assumption of efficiency ratio maximization makes this DEA study use output orientation in calculating engineering efficiency. Another orientation is to minimize input but both assumptions will get the same results. A DMU is said to be relatively efficient if its dual value is equal to 1 ( $100 \%$ efficiency value), conversely if the dual value is $<1$ then the DMU is considered to be relatively inefficient or inefficient. The modeling found in DEA is as follows:

CRS Model (constant return to scale): The constant return to scale model was developed by Charnes et al. (1978) (CCR Model). This model assumes that the ratio between the addition of inputs and outputs is the same (constant return to scale). That is if there is an additional input of $\mathrm{x}$ times, the output will increase by $\mathrm{x}$ times too. Another assumption used in this model is that each company or Decision Making Unit (DMU) operates at an optimal scale. The model of constant return to scale for each approach to measuring efficiency can be written as follows.

Intermediation approach:

$$
\begin{gathered}
\sum_{\mathrm{r}=1}^{\mathrm{s}} \mathrm{u}_{\mathrm{r}} \mathrm{y}_{\mathrm{ro}} \\
\text { Max ho }=-\sum_{\mathrm{i}=1}^{\mathrm{m}} \mathrm{V}_{\mathrm{i}} \mathrm{X}_{\mathrm{io}}
\end{gathered}
$$

Limitation or constraint function:

$$
\begin{aligned}
& \sum_{r=1}^{s} u_{r} y_{r j} \\
& -----\leq 1 ; j=1, \ldots, n ; U_{r}, V_{i} \geq 0 ; r=1, \ldots, s ; i=1, \ldots, m \\
& \sum_{i=1}^{m} V_{r} X_{i j}
\end{aligned}
$$


Where:

ho : Technical efficiency (CRS)

$\mathrm{y}_{\mathrm{rj}}$ : Output variable of 18 banks, namely: the amount of financing that is granted, operating income and current assets

$\mathrm{x}_{\mathrm{ij}}$ : Input variables from 18 banks, namely: labor costs, third party funds and fixed assets

$\mathrm{u}_{\mathrm{r}} \quad$ : Output variable weights from 18 banks

$v_{i}$ : The weight of input variables from 18 banks

$\mathrm{j} \quad$ : No. of DMUs in this case 18 banks

$r$ : No. of outputs in this case there are 3

$\mathrm{i}$ : No. of inputs in this case there are 3

\section{Production approach:}

$$
\text { Max ho }=\frac{\sum_{r=1}^{s} u_{r} y_{r o}}{\sum_{i=1}^{m} V_{i} X_{i o}}
$$

\section{Limitation or constraint function:}

$$
\begin{aligned}
& \sum_{r=1}^{s} u_{r} y_{r j} \\
& ------\leq 1 ; j=1, \ldots, n ; U_{r}, V_{i} \geq 0 ; r=1, \ldots, s ; i=1, \ldots, m \\
& \sum_{i=1}^{m} V_{r} X_{i j}
\end{aligned}
$$

Where:

ho : Technical efficiency (CRS)

$\mathrm{y}_{\mathrm{rj}}$ : Output variables of 18 banks, namely: operating income and other operating income

$\mathrm{x}_{\mathrm{ij}} \quad$ : Input variable from 18 banks, namely operational costs, labor costs work and other operational costs

$\mathrm{u}_{\mathrm{r}} \quad$ : Output variable weights from 18 banks

$v_{i}$ : The weight of input variables from 18 banks

$\mathrm{j} \quad$ : No. of DMUs in this case 18 banks

$\mathrm{r}$ : No. of outputs in this case there are 2

i : No. of inputs in this case there are 3

Efficiency values are always less or equal to 1 . A DMU whose efficiency value is $<1$ means inefficiency while a DMU whose efficiency value is equal to 1 means that the DMU is efficient.

VRS Model (variable return to scale): This model was developed by Banker, Charnes and Cooper (BCC Model) in 1984 and is a development of the CCR Model. This model assumes that the company does not or has not yet operated at an optimal scale. The assumption of this model is that the ratio between the addition of input and output is not the same (variable return to scale). This means that the addition of input $\mathrm{x}$ times will not cause output to increase $x$ times, it can be smaller or bigger than $\mathrm{x}$ times. Increasing the proportion can be Increasing
Return to Scale (IRS) or can also be Decreasing Return to Scale (DRS). Furthermore, the BCC model for each approach to measuring efficiency can be written as follows:

Intermediation approach:

$$
\operatorname{Maxho}=\sum_{\mathrm{i}=1}^{\mathrm{s}} \mathrm{u}_{\mathrm{r}} \mathrm{y}_{\mathrm{ro}}-\mathrm{U}_{\mathrm{o}}
$$

\section{Limitation or constraint function:}

$$
\sum_{\mathrm{r}=1}^{\mathrm{s}} \mathrm{u}_{\mathrm{r}} \mathrm{y}_{\mathrm{rj}} \sum_{\mathrm{i}=1}^{\mathrm{m}} \mathrm{v}_{\mathrm{i}} \mathrm{x}_{\mathrm{ijj}}-\mathrm{u}_{\mathrm{o}} \leq 0 ; \mathrm{j}=1, \ldots, \mathrm{n} ; \sum_{\mathrm{i}=1}^{\mathrm{m}} \mathrm{V}_{\mathrm{i}} \mathrm{X}_{\mathrm{io}}=1 ; \mathrm{u}_{\mathrm{r}}, \mathrm{v}_{\mathrm{i}} \geq 0
$$

Where:

ho : Allocative efficiency (VRS)

$\mathrm{y}_{\mathrm{rj}}$ : Output variable of 18 banks, namely: the amount of financing that is granted, operating income and current assets

$\mathrm{x}_{\mathrm{ij}}$ : Input variables from 18 banks, namely: labor costs, third party funds and fixed assets

$\mathrm{u}_{\mathrm{r}}$ : Output variable weights from 18 banks

$v_{i}$ : The weight of input variables from 18 banks

$\mathrm{j}:$ No. of DMUs in this case 18 banks

$r$ : No. of outputs in this case there are 3

i : No. of inputs in this case there are 3

Production approach:

$$
\text { Max ho }=\sum_{i=1}^{s} u_{r} y_{r o}-u_{o}
$$

\section{Limitation or constraint function:}

$$
\sum_{r=1}^{s} u_{r} y_{r j} \sum_{i=1}^{m} v_{i} x_{i j}-u_{o} \leq 0 ; j=1, \ldots, n ; \sum_{i=1}^{m} V_{i} X_{i o}=1 ; u_{r}, v_{i} \geq 0
$$

Where:

ho : Allocative efficiency (VRS)

$\mathrm{y}_{\mathrm{rj}}$ : Output variables of 18 banks, namely: operating income and other operating income

$\mathrm{x}_{\mathrm{ij}}$ : Input variable from 18 banks, namely: operational costs, labor costs work and other operational costs

$\mathrm{u}_{\mathrm{r}}$ : Ooutput variable weights from 18 banks

$v_{i}$ : The weight of input variables from 18 banks

$\mathrm{j}:$ No. of DMUs, in this case 18 banks

$r$ : No. of outputs, in this case there are 2

i : No. of inputs, in this case there are 3

\section{RESULTS AND DISCUSSION}

Intemediation approach: The results of tests conducted on 18 banks showed that in 2014 there were four banks that showed a level of efficiency. The four banks consist 
Int. Business Manage., 13 (9): 397-404, 2019

Table 2: Efficiency score in 2014

\begin{tabular}{|c|c|c|c|c|}
\hline & \multicolumn{2}{|c|}{ Intermediary approach CRS/VRS } & \multicolumn{2}{|c|}{ Production approach CRS/VRS } \\
\hline & SE-I & SE-O & SE-I & SE-O \\
\hline$\underline{\mathrm{DMU}}$ & Score & Score & Score & Score \\
\hline 2014-Private bank 1 & 0.978 & 0.877 & 0.884 & 0.855 \\
\hline 2014-State owned bank 1 & 0.999 & 0.998 & 0.999 & 0.972 \\
\hline 2014-Syariah bank 1 & 0.985 & 0.977 & 0.987 & 0.938 \\
\hline 2014-Syariah bank 2 & 0.968 & 0.968 & 0.939 & 0.970 \\
\hline 2014-Private bank 2 & 0.929 & 0.974 & 0.990 & 0.987 \\
\hline 2014-Private bank 3 & 1.000 & 1.000 & 0.908 & 0.899 \\
\hline 2014-Private bank 4 & 0.738 & 0.821 & 0.754 & 0.840 \\
\hline 2014-Private bank 5 & 1.000 & 1.000 & 0.811 & 0.811 \\
\hline 2014-Foreign bank 1 & 1.000 & 1.000 & 1.000 & 1.000 \\
\hline 2014-Foreign bank 2 & 0.795 & 0.795 & 0.901 & 0.856 \\
\hline 2014-Private bank 6 & 0.931 & 0.990 & 0.957 & 0.993 \\
\hline 2014-Private bank 7 & 0.965 & 0.985 & 1.000 & 1.000 \\
\hline 2014-Private bank 8 & 0.953 & 0.938 & 0.978 & 0.946 \\
\hline 2014-Private bank 9 & 1.000 & 1.000 & 0.949 & 0.985 \\
\hline 2014-Foreign bank 3 & 0.933 & 0.932 & 0.890 & 0.879 \\
\hline 2014-Private bank 10 & 0.997 & 0.997 & 0.844 & 0.839 \\
\hline 2014-Private bank 11 & 0.986 & 0.986 & 1.000 & 1.000 \\
\hline 2014-Foreign bank 4 & 1.000 & 1.000 & 1.000 & 1.000 \\
\hline
\end{tabular}

Table 3: Efficiency score in 2015

\begin{tabular}{|c|c|c|c|c|}
\hline & \multicolumn{2}{|c|}{ Intermediary approach CRS/VRS } & \multicolumn{2}{|c|}{ Production approach CRS/VRS } \\
\hline & SE-I & SE-O & SE-I & SE-O \\
\hline$\underline{\mathrm{DMU}}$ & Score & Score & Score & Score \\
\hline 2015-Private bank 1 & 0.948 & 0.857 & 0.913 & 0.865 \\
\hline 2015-State owned bank 1 & 0.981 & 0.998 & 0.999 & 0.991 \\
\hline 2015-Syariah bank 1 & 0.916 & 0.912 & 0.999 & 0.934 \\
\hline 2015-Syariah bank 2 & 0.968 & 0.968 & 0.963 & 0.984 \\
\hline 2015-Private bank 2 & 0.923 & 0.959 & 0.981 & 0.962 \\
\hline 2015-Private bank 3 & 0.980 & 0.974 & 0.922 & 0.916 \\
\hline 2015-Private bank 4 & 0.693 & 0.693 & 0.785 & 0.855 \\
\hline 2015-Private bank 5 & 1.000 & 1.000 & 0.824 & 0.830 \\
\hline 2015-Foreign bank 1 & 1.000 & 1.000 & 1.000 & 1.000 \\
\hline 2015-Foreign bank 2 & 0.958 & 0.950 & 0.824 & 0.787 \\
\hline 2015-Private bank 6 & 0.854 & 0.902 & 0.994 & 0.987 \\
\hline 2015-Private bank 7 & 0.966 & 0.983 & 0.999 & 0.999 \\
\hline 2015-Private bank 8 & 0.884 & 0.871 & 0.933 & 0.917 \\
\hline 2015-Private bank 9 & 0.878 & 0.874 & 0.976 & 0.992 \\
\hline 2015-Foreign bank 3 & 1.000 & 1.000 & 0.896 & 0.861 \\
\hline 2015-Private bank 10 & 0.997 & 0.997 & 0.828 & 0.828 \\
\hline 2015-Private bank 11 & 0.973 & 0.972 & 0.971 & 0.971 \\
\hline 2015-Foreign bank 4 & 0.999 & 0.999 & 0.921 & 0.913 \\
\hline
\end{tabular}

of two national private banks (Private Bank 5 and Private Bank 9) and two Foreign banks (Foreign Bank 1 and Foreign Bank 4). The complete results can be seen in Table 2.

In 2015 the number of banks that reached efficiency values decreased, only reaching 3 banks (Table 3 ). Consists of 1 national private bank (private bank 5) and 2 Foreign banks (Foreign banks 1 and 3). This is in line with banking conditions, particularly the BUKU II bank group which occurred in Indonesia in 2015 showing a decline in performance in terms of lending or financing as well as third party fund raising. Loans or financing provided in 2015 decreased by $19.31 \%$ compared to 2014 . For third party fund raising in 2015 also decreased by $17.27 \%$.
Furthermore, in 2016, an analysis of the level of efficiency in the BUKU II group of banks go public showed that there were only three banks that achieved it (Table 4). In contrast to 2015, in 2016 the composition consisted of two national private banks (Private Bank 5 and Private Bank 10) and one Foreign bank (Foreign Bank 1). The condition is in line with the development of banks that are included in the group of national private Foreign exchange banks that have experienced growth for loans and third-party fund raising, respectively by 9.57 and $12.32 \%$. This condition is contrary to what happened in the group of mixed banks and Foreign banks whose loans each grew by only 3.23 and $-3.84 \%$. As for the third party fund raising each grew 4.58 and $3.76 \%$. 
Int. Business Manage., 13 (9): 397-404, 2019

Table 4: Efficiency score in 2016

\begin{tabular}{|c|c|c|c|c|}
\hline & \multicolumn{2}{|c|}{ Intermediary approach CRS/VRS } & \multicolumn{2}{|c|}{ Production approach CRS/VRS } \\
\hline & SE-I & SE-O & SE-I & SE-O \\
\hline DMU & Score & Score & Score & Score \\
\hline 2016-Private bank 1 & 0.986 & 0.799 & 0.936 & $\overline{0.878}$ \\
\hline 2016-State owned bank 1 & 0.990 & 0.970 & 0.980 & 0.968 \\
\hline 2016-Syariah bank 1 & 0.981 & 0.879 & 0.971 & 0.917 \\
\hline 2016-Syariah bank 2 & 0.985 & 0.987 & 0.980 & 0.990 \\
\hline 2016-Private bank 2 & 0.958 & 0.994 & 0.983 & 0.968 \\
\hline 2016-Private bank 3 & 0.941 & 0.940 & 0.940 & 0.929 \\
\hline 2016-Private bank 4 & 0.973 & 0.996 & 0.865 & 0.881 \\
\hline 2016-Private bank 5 & 1.000 & 1.000 & 0.881 & 0.902 \\
\hline 2016-Foreign bank 1 & 1.000 & 1.000 & 0.957 & 0.999 \\
\hline 2016-Foreign bank 2 & 0.939 & 0.937 & 0.835 & 0.798 \\
\hline 2016-Private bank 6 & 0.846 & 0.883 & 0.987 & 0.995 \\
\hline 2016-Private bank 7 & 0.911 & 0.900 & 0.998 & 0.999 \\
\hline 2016-Private bank 8 & 0.900 & 0.892 & 0.929 & 0.916 \\
\hline 2016-Private bank 9 & 0.849 & 0.844 & 0.971 & 0.999 \\
\hline 2016-Foreign bank 3 & 0.980 & 0.964 & 0.938 & 0.835 \\
\hline 2016-Private bank 10 & 1.000 & 1.000 & 0.822 & 0.822 \\
\hline 2016-Private bank 11 & 0.966 & 0.966 & 1.000 & 1.000 \\
\hline 2016-Foreign bank 4 & 1.000 & 0.991 & 0.947 & 0.943 \\
\hline
\end{tabular}

Table 5: Efficiency score in 2017

\begin{tabular}{|c|c|c|c|c|}
\hline & \multicolumn{2}{|c|}{ Intermediary approach CRS/VRS } & \multicolumn{2}{|c|}{ Production approach CRS/VRS } \\
\hline & SE-I & SE-O & SE-I & SE-O \\
\hline DMU & Score & Score & Score & Score \\
\hline 2017-Private bank 1 & 0.960 & 0.777 & 0.965 & 0.912 \\
\hline 2017-State owned bank 1 & 0.969 & 0.961 & 0.926 & 0.921 \\
\hline 2017-Syariah bank 1 & 0.838 & 0.835 & 0.957 & 0.900 \\
\hline 2017-Syariah bank 2 & 0.992 & 0.993 & 0.994 & 0.998 \\
\hline 2017-Private bank 2 & 0.948 & 0.986 & 1.000 & 0.983 \\
\hline 2017-Private bank 3 & 0.961 & 0.961 & 0.972 & 0.959 \\
\hline 2017-Private bank 4 & 0.936 & 0.993 & 0.934 & 0.962 \\
\hline 2017-Private bank 5 & 1.000 & 1.000 & 0.878 & 0.996 \\
\hline 2017-Foreign bank 1 & 0.990 & 0.994 & 1.947 & 1.982 \\
\hline 2017-Foreign bank 2 & 0.954 & 0.953 & 0.837 & 0.829 \\
\hline 2017-Private bank 6 & 0.843 & 0.888 & 0.988 & 0.993 \\
\hline 2017-Private bank 7 & 0.850 & 0.847 & 0.980 & 0.977 \\
\hline 2017-Private bank 8 & 0.970 & 0.954 & 0.857 & 0.815 \\
\hline 2017-Private bank 9 & 0.799 & 0.799 & 0.973 & 0.995 \\
\hline 2017-Foreign bank 3 & 0.865 & 0.859 & 0.796 & 0.749 \\
\hline 2017-Private bank 10 & 0.896 & 0.891 & 0.768 & 0.766 \\
\hline 2017-Private bank 11 & 1.000 & 1.000 & 0.991 & 0.991 \\
\hline 2017-Foreign bank 4 & 0.934 & 0.929 & 0.945 & 0.944 \\
\hline
\end{tabular}

In 2017, the number of BUKU II banks going public that reached an efficiency level with one score reduced to only two banks (Table 5). Consists of two national private banks namely private bank 5 and private bank 11 . This condition is in line with what generally, occurs in the development of banking in general in Indonesia in the national private bank group. The development of loans and collection of third party funds showed growth, for national private Foreign exchange banks growing by 9.05 and $8.63 \%$, respectively. As for non-foreign exchange national private banks, loans grew by $18.21 \%$ and third-party fund raising grew by $17.35 \%$.

In 2018, there will be four banks capable of achieving efficiency values (Table 6), consisting of one sharia bank (Sharia Bank 2), two Foreign banks (Foreign Bank 3 and
Foreign Bank 4) and one national private bank (Private Bank 11). This condition is similar to developments in the group of Foreign banks and joint venture banks in Indonesia in 2018. Where loans grew by 22.27 and $16.70 \%$, respectively. As for third party funds, each grew by 7.59 and $8.02 \%$.

Production approach: The results of the efficiency analysis for banks in the BUKU II bank group go public with the production approach give different results from the intermediation approach. In the production approach the calculation of efficiency is based on the comparison between costs as input and income as output.

In 2014, the BUKU II banking group go public which was able to achieve efficiency totaling four banks. 
Int. Business Manage., 13 (9): 397-404, 2019

Table 6: Efficiency score in 2018

\begin{tabular}{|c|c|c|c|c|}
\hline & \multicolumn{2}{|c|}{ Intermediary approach CRS/VRS } & \multicolumn{2}{|c|}{ Production approach CRS/VRS } \\
\hline & SE-I & SE-O & SE-I & SE-O \\
\hline DMU & Score & Score & Score & Score \\
\hline 2018-Private bank 1 & 0.924 & 0.902 & 0.959 & 0.905 \\
\hline 2018-State owned bank 1 & 0.977 & 0.977 & 0.913 & 0.913 \\
\hline 2018-Syariah bank 1 & 0.830 & 0.830 & 0.812 & 0.792 \\
\hline 2018-Syariah bank 2 & 1.000 & 1.000 & 1.000 & 1.000 \\
\hline 2018-Private bank 2 & 0.950 & 0.995 & 0.994 & 0.989 \\
\hline 2018-Private bank 3 & 0.988 & 0.988 & 0.919 & 0.908 \\
\hline 2018-Private bank 4 & 0.962 & 0.996 & 0.937 & 0.994 \\
\hline 2018-Private bank 5 & 0.963 & 0.961 & 0.896 & 0.925 \\
\hline 2018-Foreign bank 1 & 0.902 & 0.902 & 0.941 & 0.983 \\
\hline 2018-Foreign bank 2 & 0.933 & 0.933 & 0.806 & 0.788 \\
\hline 2018-Private bank 6 & 0.862 & 0.901 & 0.975 & 0.998 \\
\hline 2018-Private bank 7 & 0.867 & 0.863 & 0.983 & 0.982 \\
\hline 2018-Private bank 8 & 0.999 & 0.997 & 0.887 & 0.862 \\
\hline 2018-Private bank 9 & 0.826 & 0.825 & 1.000 & 0.979 \\
\hline 2018-Foreign bank 3 & 1.000 & 1.000 & 1.000 & 1.000 \\
\hline 2018-Private bank 10 & 0.912 & 0.872 & 0.696 & 0.696 \\
\hline 2018-Private bank 11 & 1.000 & 1.000 & 0.933 & 0.933 \\
\hline 2018-Foreign bank 4 & 1.000 & 1.000 & 1.000 & 1.000 \\
\hline
\end{tabular}

It consists of two Foreign banks (Foreign Banks 1and 4), two national private banks (Private Banks 7 and 11). The conditions experienced were in line with the growth in costs and income that occurred at the national and Foreign exchange and non-foreign exchange private banks. Where in the group the ratio of operating costs to operating income by 85 and $92 \%$. As for the group of Foreign banks and joint venture banks, the ratio of operating costs to operating income was 79 and $80 \%$, respectively.

To achieve efficiency with the production approach in 2015 there was only one Foreign bank, namely Foreign bank 1 . This condition is generally in accordance with the development of banks in Indonesia in the period 2015. Where in that year general banking showed a decrease in operating profit of Rp. 143,761 billion in 2014 to Rp. 133,198 billion.

The same thing happened in 2016 where there was one bank that achieved the value of efficiency but was achieved by private bank 11 . Seeing the condition of banks in Indonesia in 2016, then it has a match. Where the national private Foreign exchange commercial bank group has a fairly high operating profit growth.

Furthermore in 2017, none of the banks has been able to achieve efficiency values in both the input and output approaches. However, if based on the value of the efficiency of the input approach, then there is only one bank, namely private bank 2 . In addition there are three banks whose values are nearly close to one (above 0.990) for the value of the output approach efficiency, namely shariah bank 2 , private bank 6 , private bank 11 . This is in accordance with the condition of earnings growth that occurred in the national private bank group both Foreign exchange and non-foreign exchange in 2017. The national private Foreign exchange banking group experienced operating profit growth of $31.55 \%$ while the national private non-Foreign operating profit grew by $141.48 \%$.
To be determined in 2018, BUKU II banks go public, capable of achieving efficiency totaling three, namely two Foreign banks (Foreign Banks 3 and 4) and one shariah bank (shariah Bank 2). This shows that the development of sharia banking is able to show the level of efficiency in line with non-sharia banking starting in 2018.

\section{CONCLUSION}

Efficiency is an inseparable part of the bank in carrying out its operations. For banks, especially, the BUKU II group of banks went public, it was also a matter that was sought. Efficiency assessment for the period 2014-2018 using an intermediation and production approach gives different results. In the intermediation approach, there are four national private banks (Private Bank 5, Private Bank 9, Private Bank 10, Private Bank 11) capable of achieving efficiency values, three Foreign banks (Foreign Bank 1, Foreign Bank 3, Foreign Bank 4) and one shariah bank (Shariah Bank 2). As for the production approach, during 2014-2018 there were two national private banks (Private Bank 7, Private Bank 11), three Foreign banks (Foreign Bank 1, Foreign Bank 3, Foreign Bank 4) and one shariah bank (Shariah Bank 2).

\section{REFERENCES}

Charnes, A., W.W. Cooper and E. Rhodes, 1978. Measuring the efficiency of decision making units. Eur. J. Operat. Res., 2: 429-444.

Coelli, T.J., D.S.P. Rao and G.E. Battese, 1996. Introduction to Efficiency and Productivity Analysis. Kluwer Academic Publishers, Boston, Massachusetts, USA.,. 
Denizer, C., M. Dinc and M. Tarimcilar, 2000. Measuring Banking Efficiency in the Pre-and Post-Liberalization Environment: Evidence from the Turkish Banking System. Vol. 2476, World Bank, Washington DC., USA., Pages: 58.
Farrell, M.J., 1957. The measurement of productive efficiency. J. R. Stat. Soc. Ser. A, 120: 253-290.

Kumbhakar, S. and C.A.K. Lovell, 2000. Stochastic Frontier Analysis. 1st Edn., Cambridge University Press, New York. 